\title{
THE ANNALS OF IOWA,
}

\author{
BY THE
}

\section{STATE HISTORICAL SOCIETY,}

IOWA CITY, JANUARY, 1864.

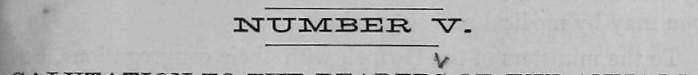

SALUTATION TO THE READERS OF THE ANNALS. BY THE EDITOR.

A new year's happy salutation to the many readers of the Annals of Iowa! To the industrious farmers, rejoicing with the song of "harvest home," the Editor of the Annals sends good cheer! Though the crops of the season past have been shortened by unusual drouth and unseasonable frost, yet the prices of produce have been enhanced, to reward the labors of the husbandmen of Iowa.

Good cheer, also, to the mechanics, a noble and necessary class of society! Your ranks have been thinned by volunteers in the army and navy of the United States, making you, who remain at home, more business and less leisure for reading and self-culture. But the long winter evenings will afford time for mental improvement. Did you ever think how high is yotir vocation? Jesus Christ, the architect of the Univer'se, was a mechanic-a "carpenter's son."

A happy new year, likewise, to the teachers of youth and their scholars in the common District Schools, in the Academies, Colleges, and University of Iowa! You act on mind and not crude matter. Your impressions given or received, from being teachers or being taught, will be eternal as truth, the object of all true science. Ascend, higher and higher, the hill of science, this year, with light and nimble steps of joy.

To the members of the legal profession, who have to do with eternal principles of justice, joy is wished, while threading the 
intricacies and uncertainties of the law, "whose seat is the bosom of God." Prostitute no time nor talents in 1864, by making the worse appear the better reason, or in perverting justice, either as advocates or judges, in this goodly land of Iowa.

To the physicians, who study and practice the healing art, may prosperity and success be sent. Yours is not only the privilege of ministering to the body but to the "mind diseased." Remember the poor, in your calling, as did the Great Physician, who when among men, healed the sick, and opened the eyes of the blind, and made the lame to walk, by miracle, as you may by medical and surgical art.

To the ministers of the Gospel, with their congregations, be good cheer and great joy, this year, as angels rejoice over their work, without which earth would be desolate, and heaven want many an inhabitant, sent there, after life's duty is done, through their instrumentality.

'Tis not a cause of small import, The Pastor's care demands ;

But what might fill an angel's heart;

It filled a Savior's hands.

To the magistrates and legislators of Iowa, a State now numbering over seven hundred thousand souls, salutation is sent. The institutions over which as Governor, or Senator, or Representative, or Judge, y'ou preside, live, when those who have acted their part, well or ill, have passed away, Ind your acts will make a part of the Documentary History of a great and growing State, when some future historian shall place them on lasting record.

And to the delegation in the Congress of the United States, strong and resolute for the right, be multiplied joys and greetings, as acting well their part for Iowa on the great stage of American conflict for a nation's life, and liberty to all the inhabitants of the land.

And last, but not least, to the patriotic soldiers and sailors, who have volunteered in the army and navy, at their country's call, cheer upon cheer be heralded through the State and Nation. And may the good Ladies' Aid Societies and State Commission minister in camp and field, in hospital and prison, 
to their joy. And may the God of battles preserve and return them to their homes, the great rebellion being crushed, and peace and prosperity restored throughout the land. And may He bless the labors of the Adj. General and Provost Marshals, with all under their orders, in swelling the ranks of the grand army and navy of the nation, for a consummation so devoutly to be desired.

\section{DAKOTA HISTORICAL SOCIETY.}

Correspondence and exchange have been opened with this newly organized Society of Dakota Territory, instituted at Yankton. A map of the Territory, with the Indian mounds noted upon it, has been received. The Secretary of the Society, Mr. B. M. Smith, states that lectures are begun before the Association, and that they are to be published and furnished, with duplicate Indian curiosities, in exchange. Our Historical Society has already sent the Secretary at Yankton twenty volumes of Laws, Reports and Documents of Iowa, with sundry pamphlets.

The citizens of Dakota have not begun too soon to gather the history of their Territory; and they will do well to seek Legislative aid, to prosecute their historical collections with diligence and perseverance.

\section{THE ESSEX INSTITUTE.}

The Essex Institute at Salem, Mass., is a most efficient Historical Association, with Henry Wheatland, Esq., as its accomplished Secretary. Historical collections are regularly published, in a Magazine form, and sent us, in exchange, for the Annals of Iowa, A large list of Laws of Massachusetts, Boston Almanacs and Directories, with numerous pamphlets, have been sent to our Society, in exchange for which twenty volumes and several pamphlets have been forwarded. 
Copyright of Annals of Iowa is the property of State of Iowa, by \& through the State Historical Society of Iowa and its content may not be copied or emailed to multiple sites or posted to a listserv without the copyright holder's express written permission. However, users may print, download, or email articles for individual use. 